\title{
Importance of Medicinal Plants
}

\author{
Hisham Ali Salem Ali* \\ Hamad Medical Corporation, Egypt \\ *Corresponding Author: Hisham Ali Salem Ali, Hamad Medical Corporation, Egypt.
}

Received: January 30, 2021

Published: February 27, 2021

(C) All rights are reserved by Hisham Ali

Salem Ali.
There is no existence of life without plants. Plants are the essential foundation of medicine. Some important drugs that are still in use today are derived from traditional medicinal herbs. The hunt for new medicines has engaged ethnobotany and ethnopharmacology-a new route as an important source of knowledge, which led toward different sources and classes of compounds. Nowadays, studies on structure-activity relationships, and their impact on the design of novel drugs have rendered them one of the utmost valuable and thus significant accomplishments of pharmacochemistry, an advance constituent in the group of pharmaceutical sciences. In this paper, we have discussed the historical importance of medicinal plants, geographical importance throughout the world, some important historical observations of medicinal plants, and leading drugs of plant origin which are still being used to treat various ailments, with or without any structural modifications. Solid evidences can be cited in favor of herbs being used for the treatment of diseases and for restoring and fortifying body systems in ancient systems of medicine such as Ayurvedic, Unani, and Chinese traditional medicine. The innately desired purpose of the use of herbs was to obtain a positive interaction with body chemistry.

\section{Islamic importance of medicinal plants}

People having different academic and intellectual backgrounds believe in Islam. Date palm's (Phoenix dactylifera) significance is described in this verse of the Holy Quran. "And from the fruits of date-palms and grapes, you drive strong drink and goodly provision" (Surah-an-Nahl, Verse no. 67). Importance of garlic (Allium sativum) is given in Verse no.61, Surah Baqarah. The importance of garlic, cucumber, lentils, and onion is described in Verse no. 61, Surah Baqarah. The value of ginger is described in Surah Ad-Dahr Chapter no. 76, Verse no. 17. In Ahaidth, the significance of many medicinal-plant species has been described by Farooqi in his book Ahaidth Mei n Mazkoor Nabatat, Adwiyah Aur Ghizaen (translated in English as "Plants, Medicines and Food Mentioned in Ahaidth"). It has citations of about 70 plants and various plant products.

\section{Early modern age}

A majority of the population in the developing world is struggling to raise living standards and improve health-care delivery due to increasing poverty and population. According to an estimate, 70 - $80 \%$ of the developing world is dependent on conventional plantobtained remedies, as pharmaceuticals are high priced. The supposed "Green Wave" activated by rising bionomical consciousness has led to increased involvement in herbal formulations all over the globe. Medicinal plants' consumption has doubled in the west. The number of plant-derived medicaments or health foods has increased slowly to encounter demands.

I will be discussing briefly a very important medicinal plant in my full research that will be sent soon and it's going to have a great breakthrough and impact in the treatment on covid-19 and other related diseases.

\section{Assets from publication with us}

- Prompt Acknowledgement after receiving the article

- Thorough Double blinded peer review

- Rapid Publication

- Issue of Publication Certificate

- High visibility of your Published work

Website: www.actascientific.com/

Submit Article: www.actascientific.com/submission.php

Email us: editor@actascientific.com

Contact us: +919182824667 